ーコミュシターションー

\title{
電位分布 測定システムの開発
}

\author{
金児紘 征*, 松田清**
}

\section{A Development of Measuring System for Potential Distribution}

\author{
Hiroyuki KANEKO* and Kiyoshi MATSUDA**
}

\section{1 緒 言}

金属を電解質中に浸せきすると。種々の原因により金 属表面にマクロ局部電池が生成し, 電気化学的に不均一 な金属表面となって腐食が進行することが多い，したが $っ て$, 金属表面の電位分布を時々刻々に測定すれば，測 定電位の高低から直接にアノードとカソードの位固を微 視的に検出することができ，さらに，その結果から腐食 の状況を観察することができるものと思われる。このよ うな観点から，これまで，ルギン管センサーを試料面上 を駆動させて試料面の電位分布を測定する技術を開発し てきたが1,2)，ここでは，オンラインで電位分布図まで作 成するマイクロコンピュータを用いた電位分布測定シス テムについてその結果を検討する.

\section{2 実験}

，電位分布測定システムをFig. 1 亿示す。この測定シス テムは電位分布測定部々電位分布図作成部からなる。電 位分布測定のために，ルギン管を上下（Z）には手動， 前後 $(\mathrm{X})$ ，左右 $(\mathrm{Y})$ にはシンクロナスモータで微動で きるようになっており，Z位置を固定しマイクロコンピ ュータからの指令により自動的にX方向一掃引した後に Y方向に一定距離だけ微動し，ふたたびX方向へ掃引す る操作を䋳返して試料面上を掃引した. 試料面上のルギ ン管のX，Y位置はポテンショメータの抵抗変化を電圧 変化に変換して測定した. 試料金属の電位はルギン管と 塩橋で連絡した $\mathrm{KCl}$ 飽和の $\mathrm{Ag} / \mathrm{AgCl}$ 電極を基準にして 高インピーダンスのデジタルボルトメータで測定し, $\mathrm{AD}$ 変换した後にオンラインでマイクロコンピュータに 入力した，電位分布図作成部はマイクロコンピュータ， CRT ディスプレー，プリンタ，テープレコーダからな る. マイクロコンピータからの指令に基づいて, 逐次, ルギン管の駆動につれ一定距離間隔で測定データをとり 込み，CRTディスプレーに测定位置, 测定電位を表示

\footnotetext{
* 秋田大学鉱山学部治金学科（率 010 秋田市手形学園町 1-1) Department of Metallurgy, Mining College, Akita University (1-1, Tegata-gakuencho, Akita)

**理化学研究所 ( $\overline{\mathbf{T}} 351$ 和光市広沢 2-1)

The Institute of Physical and Chemical Research (2-1, Hirosawa, Wako, Saitama)
}

した. 一連の測定が終了した後, 測定データをテープに 格納し，測定位置，測定電位を記載した表を作成しプリ ンタで打ちだした，電位分布図をCRTディスプレーに 表示させる場合には画面上の所定の座標位置に電位の高 低を輝度に変換した濃淡像で表示した。また，電位分布 図をプリンタで作成する場合には测定電位を適当な電位 間隔で分割して文字で対応させて所定の座標位置にプリ ンタで打ちだし，同一文字部分をたどることにより等電 位線図を作図した。なお，コンピュータの処理速度を增 ナため, データのマイクロコンピュータへのとり込み， テープへの格納には機械語を用いてプログラムを作成し た.

\section{3 結果と考察}

この電位分布測定システムの有効性を確かめるため, 一例として，銅板の一部に亜鉛をメッキしたガルバ二腐 食系の電位分布を測定し，電位分布図と試料面形状との 対态を調べた。試料面は周囲をパラフィンで被覆した $16 \mathrm{~mm} \times 20 \mathrm{~mm}$ の電解銅表面の中心部に $8 \mathrm{~mm} \times 2 \mathrm{~mm}$ の寸法で亜鉛をメッキし，1500\#芒の耐水ベーパで研 摩してメッキ厚さを $20 \mu \mathrm{m}$ 以下にしたもので，亜鉛/銅 面積比は 0.053 である. 電位分布測定は $25^{\circ} \mathrm{C}$, 空気飽 和の $0.01 \mathrm{~mol} \mathrm{dm}^{-3} \mathrm{NaCl}$ 中で定常電位分布に達した後,

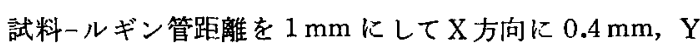
方向に $0.8 \mathrm{~mm}$ 間隔で測定した。測定所要時閒は $600 \mathrm{~s}$ である。その測定結果をFig. 2 に示す。図から明らか なように，試料面上の銅部，亜鉛部の形状と電位分布は 非常によく対応し，亜鉛部がアノードで銅部がカソード となっており，その電位差は約 $150 \mathrm{mV}$ である。 0.01 $\mathrm{mol} \mathrm{dm}{ }^{-3} \mathrm{NaCl}$ 中では銅, 亜鉛の腐食電位はそれぞれ 約 $-950 \mathrm{mV},-80 \mathrm{mV}$ vs. $\mathrm{Ag} / \mathrm{AgCl}$ (飽和 $\mathrm{KCl}$ ) であ るが，このガルバ二腐食系の分極特性はカソード支配型 であるために，亜鉛部はほとんど分極されないのに対し 銅部が著るしく分極されることが明らかである、したが って,この電位分布測定法によれば, 陚料面上のアノ一 ドとカンードの位置掞よび分極の程度が明らかとなり， 電位分布測定法が金属表面の電気化学的性質を調べる非 常に有用な測定法であることを示している.

この測定法で，微小ルギン管を用いて $0.1 \mathrm{~mm}$ 以下の 


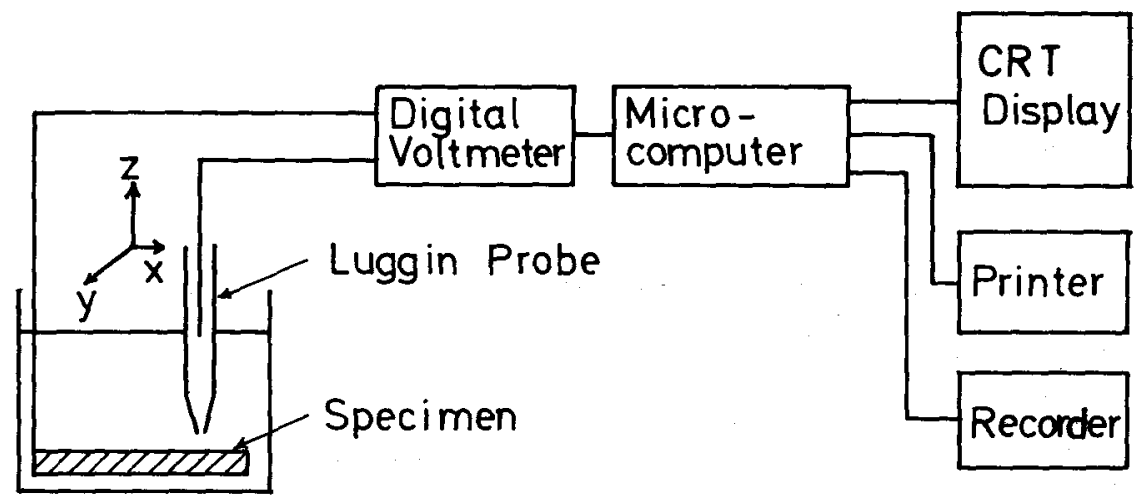

Fig. 1 Block diagram of the measuring system,

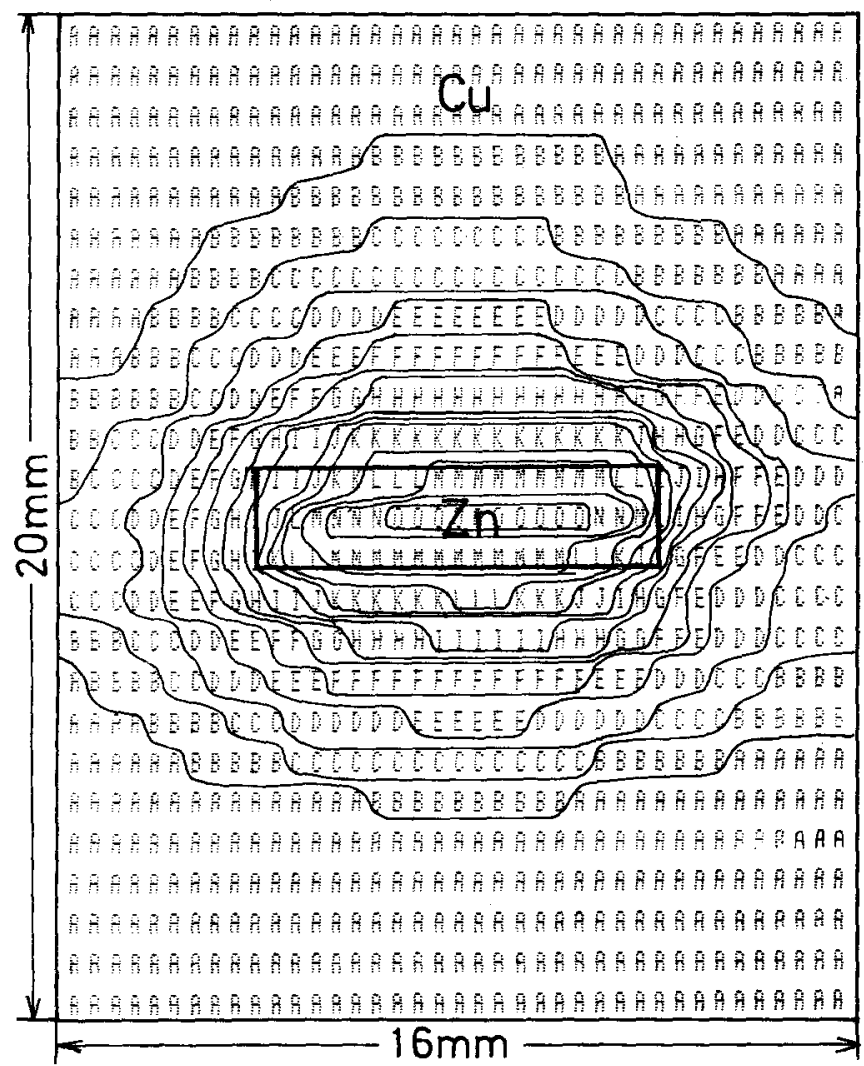

Fig. 2 Potential distribution of a copper-zinc galvanic couple in 0.01 mol $\mathrm{dm}^{-3} \mathrm{NaCl}$ aqueous solution at $25^{\circ} \mathrm{C}$. ( Luggin probe-specimen distance: $1 \mathrm{~mm}$, Measuring time: 600s) $-800>A>-820>B>-830>C>-840>D>$ $-850>\mathrm{E}>-860>\mathrm{F}>-870>\mathrm{G}>-880>\mathrm{H}>$ $-890>\mathrm{I}>-900>\mathrm{J}>-910>\mathrm{K}>-920>\mathrm{L}>$ $-930>\mathrm{M}>-940>\mathrm{N}>-950>0>-960$ $\mathrm{mV}$ vs. $\mathrm{Ag} / \mathrm{AgCl} / \mathrm{sat} . \mathrm{KCl}$

分解能で微視的測定をすることむ十分可能であり，デー タの上り迲みを高速化して測定を繰返せば，電位分布の 時間的推移から金属表面の應食過程を詳細にたどること ができるものと思われる、また，この電位分布測定法で 試料一ルギン管距離を変えて同様の測定をすれば，オー ムの法則が適用できる条件下で容易に電流分布測定法上 ナることもできる，さらに，適当なセンサ一を選べば， $\mathrm{pH}$ 分布, 溶出金属イオン篊度分布などを測定できる可 能性もあり，金属/電解質水溶液界面の不均一性を調心
るために広範团の応用が考えられる。

本研究を遂行するにあたり，有益なご助言を賜わりま した理化学研究所玉虫佮太主任研究員に厚く感謝いた します。

\section{文献}

1）金児紘征，日本金属学会誌，42，381 (1978).

2）金児紘征，鎌田宏之，日本金属学会誌，46，387 (1982).

(Received Apr. 26, 1982 ; Accepted May 13, 1982) 